\title{
An antioxidant activity of the whole body of Holothuria scabra
}

\author{
Saksit Nobsathian ${ }^{1 *}$, Patoomratana Tuchinda ${ }^{2}$, Prasert Sobhon ${ }^{3}$, Yotsawan Tinikul $^{1}$, Jaruwan Poljaroen ${ }^{1}$, \\ Ruchanok Tinikul ${ }^{1}$, Morakot Sroyraya ${ }^{1}$, Tanes Poomton ${ }^{4}$ and Supakant Chaichotranunt ${ }^{4}$
}

\begin{abstract}
Background: Holothuria scabra is the potential source of terpene with high antioxidant capacity and one of the most valuable species in the trade.

Results: The results indicated that antioxidant activity of crude methanol extracts and three pure compounds, Friedelin, 3-Hydroxybenzaldehyde and 4-Hydroxybenzaldehyde, from sea cucumber was determined using DPPH, Folin-Cioccalteau reagent. The results indicated the total phenolic contents at 30.52.28 $\pm 0.21 \mathrm{GAE} / \mathrm{g}$ dry weight equivalent and the effective concentration $\left(\mathrm{EC}_{50}\right.$ ) value were found to be $33.77 \pm 0.24,14.63 \pm 0.01,14.62 \pm 0.01$ and $14.78 \pm 0.11 \mathrm{mg} / \mathrm{ml}$ whole body of Holothuria scabra, Friedelin, 3-Hydroxybenzaldehyde and 4-Hydroxybenzaldehyde, respectively.

Conclusion: In conclusion, the methanol extract and pure compounds of whole body parts of sea cucumber showed the highest antioxidant activity with $\mathrm{EC}_{50}$ value of $33.77 \pm 0.24,14.63 \pm 0.01,14.62 \pm 0.01$ and $14.68 \pm 0.11$ $\mathrm{mg} / \mathrm{ml}$. It also showed the highest total phenolic content at $30.52 \pm 0.21 \mathrm{GAE} / \mathrm{g}$ dry weight.
\end{abstract}

Keywords: Sea cucumber, DPPH, Holothuria scabra, Total phenolic content, Triterpene glycoside

\section{Background}

Free radicals are highly active atoms or molecules with unpaired valence electron [1]. They play an important role in human body, such as involvement in the energy creating process, the cell growth, the signalling process and immunization process [2]. However, owing to their high activity, they can cause various cell and tissue disorders as well as destruction or modification of DNA structure [3]. All of these lead to cell death, gene abnormalities and cancer [4].

Terpenes are large and diverse class of organic compounds, produced by a variety of plants, microbes and animals. It comprises a high variety particularly of more than 100,000 different structures [5] which can be divided into several sub-groups, such as monoterpenes, sesquiterpenes, diterpenes and triterpenes. All these

\footnotetext{
*Correspondence: Saksit.nob@mahidol.ac.th

${ }^{1}$ Nakhonsawan Campus, Mahidol University, 402/1 Moo 5 Khaothong,

Phrayuhakiri District, Nakhonsawan 60130, Thailand

Full list of author information is available at the end of the article
}

compounds can be naturally found in foods and beverages from plants, animals, and microbes, and can inhibit or eliminate free radicals from the body [6].

Sea cucumber, Holothuria spp., is one of the most common shallow-water tropical sea cucumbers in the IndoPacific, spanning from Madagascar to French Polynesia [7]. It is a new source for a wide range of bioactive compounds with medical utilization [8]. Water extract from Holothuria edulis [9] was proved to show antibacterial activity, as well as the methanol extract of body wall of Holothuria leucospilota [10]. Scabraside D from Holothuria scabra was reported to induce apoptosis and inhibit growth of human cholangiocarcinoma xenografts in mice [11]. This group of substances shows various biological activities, including antifungal, cytotoxic, haemolytic, cytostatic and immunomodulatory effects. The chloroform extract of whole body of Holothuria mobiles gave a positive result on antitumor [12]. In addition, the methanolic extract of whole body of Holothuria atra showed 
antibacterial (Klebsiella pneumoniae, Serratia liquefaciens and Staphylococcus aureus) activity [13].

In this study, we focused on $H$. scabra, commonly known as sandfish, and one of the most valuable species in the trade [14], is a marine invertebrate in the family Holothuriidae. Holothuria scabra has the same general anatomy as other sea cucumbers. The gonads (ovaries or testes) lie in one tuft and open dorsally at the anterior end of the body through a single gonopore (i.e. genital orifice). The digestive system is composed of a mouth, oesophagus, stomach, intestine, cloaca and anus. Respiratory trees, which sandfish use to obtain oxygen, lie in the posterior of the body and open to the cloaca. The body wall that is processed into bêche-de-mer accounts for about $56 \%$ of total weight. Sandfish move with the help of tube feet densely distributed on the ventral face, and through muscular action of the body wall. Sandfish feed on detritus, i.e. organic matter in the mud or sand. They appear to feed continuously using the peltate tentacles surrounding the mouth to place sediment into the mouth. Sandfish are usually observed partially buried in sediment. The daily burrowing cycle varies according to environmental conditions. They are found in the tropical Indo-Pacific region, extending from the Red Sea and East Africa to Australia. It normally lives on the seabed, in shallow waters on reefs and sand flats and in seagrass meadows up to $20 \mathrm{~m}$ deep. Its colour makes it conspicuous, but its body often camouflaged by a coating of sand which also protects it from the sunlight. Humans have eaten these animals for centuries. For example, the Chinese have been harvesting them from the waters of Malaysia and Australia for at least 1000 years. They are eaten in soups, raw as sushi and as appetizers and delicacies. The raw or pickled body and internal organs are called "konowata" by the Japanese and the salted, fire- or sun-dried body wall is known worldwide as "beche de mer" literally translated as "beast of the sea" [15]. The isolation of natural compounds from the whole body of this animal afforded three compounds, friedelin (1) [16], 3-hydroxybenzaldehyde (2) [17] and 4-hydroxybenzaldehyde (3) [17] showed in Fig. 1.

\section{Methods}

General experimental procedure

Sodium tungstate, disodium molybdate, lithium sulphate, gallic acid, aluminium trichloride, L-ascorbic acid and anhydrous sodium carbonate were purchased from Wako pure chemical industries Ltd. Methanol, sodium hydroxide, sodium nitrite and quercetin were purchased from Merck Co. 2,2,-diphenyl-2-picrylhydrazyl (DPPH) was purchased from Sigma Chemical Co. UV spectrophotometer (Jenway 7315 spectrophotometer) was used for measuring the data. The ${ }^{1} \mathrm{H}$-NMR and ${ }^{13} \mathrm{C}$-NMR spectra were recorded on a Bruker AscendTM $400 \mathrm{MHz}$ or Bruker ADVANCE $500 \mathrm{MHz}$.

\section{Extraction of sea cucumber}

Adult H. scabra was obtained from the Coastal Fishery Research and Development Center, Prachuap Khiri Khan Province, Thailand, and is shown in Fig. 2. The bodies of H. scabra were minced into small pieces, and followed by extraction with methanol. The methanol extracts from each part were evaporated and collected for studies.

The methanol fraction (11.22 g) of whole body part was separated by column chromatography on silica gel $\left(\mathrm{SiO}_{2}\right.$, $200 \mathrm{~g})$, eluting with methanol in dichloromethane $(0,2,4$, $6,8,10,15,20,25,30,35,40,50,55,60,65,70,80,90$ and $100 \%, 10 \mathrm{~L}$ each). Fractions were combined to give 6 fractions $\left(\mathrm{A}_{1}-\mathrm{A}_{6}\right)$. Fraction $\mathrm{A}_{3}(1.19 \mathrm{~g})$ was further isolated by column chromatography on silica gel (10\% dichloromethane-hexane) to give fractions $B_{1}-B_{4}$. $B_{2}$ gave yellow powder after recrystallization from EtOAc and was identified as 4-hydroxybenzaldehyde $(3)(76.1 \mathrm{mg}) . \mathrm{B}_{3}$ gave brown

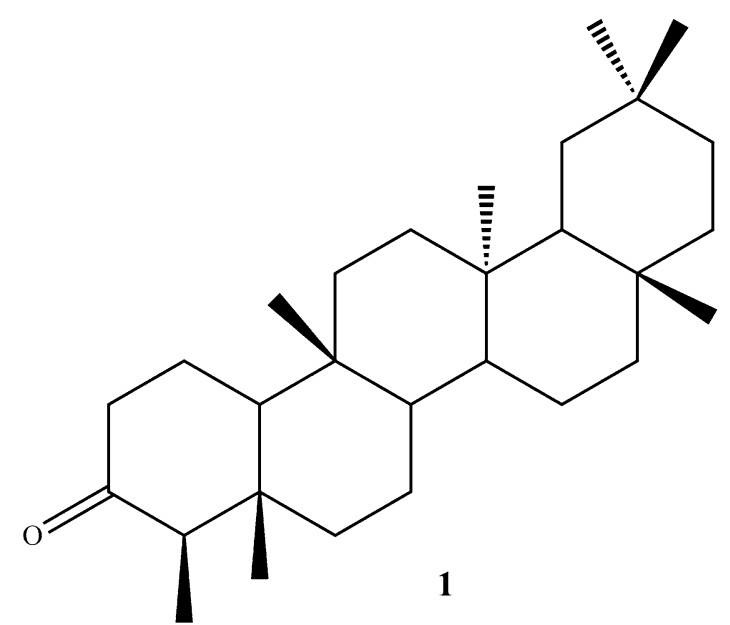

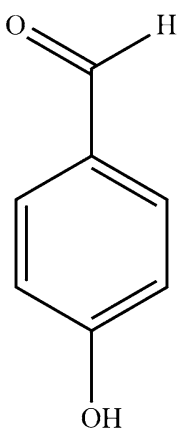

2

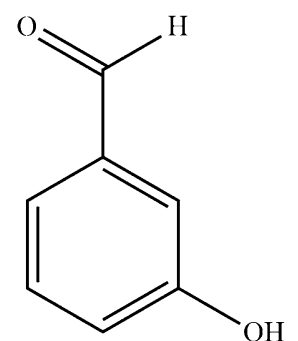

3

Fig. 1 Friedelin (1), 3-hydroxybenzaldehyde (2) and 4-hydroxybenzaldehyde (3) were isolated from H. scabra 


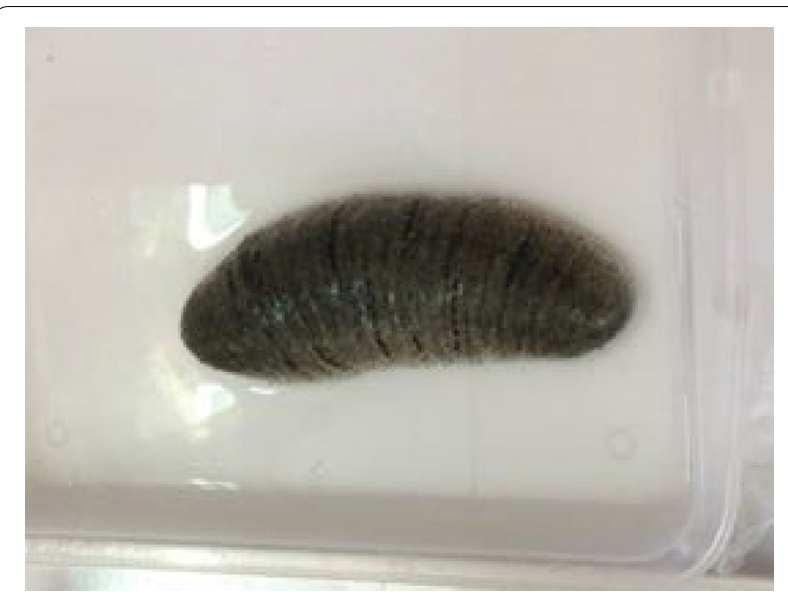

Fig. 2 Adult Holothuria scabra was obtained from the Coastal Fishery Research and Development Center, Prachuap Khiri Khan Province, Thailand

powder after recrystallization from methanol and was identified as 3-hydroxybenzaldehyde (2) $(88.1 \mathrm{mg})$. The fraction $\mathrm{A}_{4}$ was purified by on Sephadex LH-20 column, using $100 \%$ methanol as eluent to give friedelin (50.14 mg) as white powder. The chemical structure of friedelin (1), 3-hydroxybenzaldehyde (2) and 4-hydroxybenzaldehyde (3) was determined using ${ }^{1} \mathrm{H}$ and ${ }^{13} \mathrm{C}$ NMR spectra.

\section{Determination of total phenolic content}

$10 \mathrm{~g}$ of sodium tungstate and $2.5 \mathrm{~g}$ of sodium molybdate were dissolved in $80 \mathrm{ml}$ of water, and then $5 \mathrm{ml}$ of conc. phosphoric acid and $10 \mathrm{ml}$ of conc. $\mathrm{HCl}$ were added and refluxed for $10 \mathrm{~h}$. After cooling, $15 \mathrm{~g}$ of lithium sulphate, $5 \mathrm{ml}$ of water and 4-6 drops of bromine were added. The solution was further boiled for $15 \mathrm{~min}$ and cooled. The filtration of mixture gave yellow solution.

The total phenolic content of the crude extracts was determined using folin-ciocalteau reagent [18]. $800 \mu \mathrm{l}$ of folin-ciocalteau reagent, $2.0 \mathrm{ml}$ of $7.5 \%$ of sodium carbonate and $4 \mathrm{ml}$ of deionized water were added to $200 \mu \mathrm{l}$ of test sample and shaken. After incubation for $90 \mathrm{~min}$ in the dark room at room temperature, the solution turns into blue colour. The absorbance of mixtures was measured at $765 \mathrm{~nm}$ using UV-VIS spectrophotometer. The calibration curve was plotted from standard gallic acid solution in ethanol with a concentration of $5-30 \mu \mathrm{g} / \mathrm{ml}$, and used for the calculation of the phenolic content gallic acid equivalents GAE/g.

\section{Determination of anti-oxidation DPPH assay}

The free radical scavenging activity of black sea cucumber was determined using the 2,2,-diphenyl-2-picrylhydrazyl (DPPH) spectrophotometric method according to the study of Brand-Williams et al. [19] with some modifications. In brief, samples $(1000 \mu \mathrm{g} / \mathrm{ml}$ in ethanol, $100 \mu \mathrm{l})$ were mixed with $200 \mu \mathrm{l}$ of an ethanolic DPPH $(2 \mathrm{mM})$. Then $3 \mathrm{ml}$ of distilled water was added and the mixtures were incubated for $30 \mathrm{~min}$ in dark. The absorbances of sample were measured at $516 \mathrm{~nm}$ using UV-VIS spectrophotometer. The percentage of the DPPH free radical was calculated using the following equation:

$$
\% \text { Inhibition }=\left(1-\left(\mathrm{A}_{\text {sample }} / \mathrm{A}_{\text {control }}\right)\right) \times 100 .
$$

The percentage of remaining DPPH was plotted against extract concentration $(\mu \mathrm{g} / \mathrm{ml})$ to obtain half maximal effective concentration $\left(\mathrm{EC}_{50}\right)$.

\section{Statistical analysis}

The data were expressed as mean \pm standard deviation (SD). Statistical significance difference phenolic content was analysed from the variance (one-way ANOVA). Differences at a $95 \%(P<0.05)$ confidence level were considered statistically significant. Correlations between the evaluated parameters were obtained using Pearson's correlation coefficient (r). All analyses were carried out in triplicate.

\section{Results and discussions}

The methanol extracts were prepared to examine the total phenolic content and antioxidant activity. The percent yield of extract obtained from $50 \mathrm{~g}$ of dry material was measured for each extract. The yield of methanol extract was whole body $22.24 \%$.

The phenolic contents of the parts of sea cucumber were determined using the standard plot of gallic acid $\left(\mathrm{Y}=0.0041 \mathrm{X}-0.0016, \mathrm{R}^{2}=0.9993\right)$ and found to be $30.52 \pm 0.21 \mu \mathrm{g} / \mathrm{g} \mathrm{d}$ wt.

The results of DPPH free radical scavenging activity on the crude methanol extracts and pure compounds of the sea cucumber are shown in Table 1. Percentage scavenging activity of crude methanol extract at $50 \mu \mathrm{g} / \mathrm{ml}$ concentrations of whole body of $H$. scabra was found to be $72.00 \pm 0.43 \%$. The effective concentration $\left(\mathrm{EC}_{50}\right)$ values were found to be $33.77 \pm 0.24 \mu \mathrm{g} / \mathrm{ml}$ and $\mathrm{R}^{2}=0.9991$ for whole body. Percentage scavenging activity at $25 \mu \mathrm{g} /$ $\mathrm{ml}$ concentrations of friedelin (1), 3-hydroxybenzaldehyde (2) and 4-hydroxybenzaldehyde (3) were found to be $90.22 \pm 0.15,92.44 \pm 0.09$ and $91.23 \pm 0.33 \%$. The effective concentration $\left(\mathrm{EC}_{50}\right)$ values were found to be $14.63 \pm 0.01,14.62 \pm 0.01$ and $14.78 \pm 0.11 \mu \mathrm{g} / \mathrm{ml}$. The regression coefficient $\left(R^{2}\right)$ of pure compounds was shown at $0.9992,0.9993$ and 0.9979 . Ascorbic acid was used as positive control.

There was a strong relationship between total phenol content and antioxidant activity, as phenols possess strong free radicals scavenging ability. Therefore, the 
Table 1 The antioxidant activity of crude extracts of different parts of black sea cucumber

\begin{tabular}{|c|c|c|c|c|}
\hline Type of extract & Concentration $(\mu \mathrm{g} / \mathrm{ml})$ & $\%$ inhibition & Regression equation & $\mathrm{EC}_{50}(\mu \mathrm{g} / \mathrm{ml})$ \\
\hline \multicolumn{5}{|l|}{ Crude extract } \\
\hline \multirow[t]{5}{*}{ Whole body } & 10 & $18.89 \pm 0.09$ & $Y=1.3255 X+5.341$ & $33.77 \pm 0.24$ \\
\hline & 20 & $32.08 \pm 0.17$ & & \\
\hline & 30 & $44.00 \pm 0.23$ & & \\
\hline & 40 & $58.11 \pm 0.17$ & & \\
\hline & 50 & $72.00 \pm 0.43$ & & \\
\hline \multicolumn{5}{|l|}{ Pure compound } \\
\hline \multirow[t]{5}{*}{ Compound 1} & 5 & $14.44 \pm 0.15$ & $Y=3.8008 X-5.6$ & $14.63 \pm 0.01$ \\
\hline & 10 & $31.52 \pm 0.08$ & & \\
\hline & 15 & $50.88 \pm 0.74$ & & \\
\hline & 20 & $70.00 \pm 0.09$ & & \\
\hline & 25 & $90.22 \pm 0.15$ & & \\
\hline \multirow[t]{5}{*}{ Compound 2} & 5 & $9.56 \pm 0.15$ & $Y=4.1796-11.094$ & $14.62 \pm 0.01$ \\
\hline & 10 & $30.11 \pm 0.08$ & & \\
\hline & 15 & $52.56 \pm 0$ & & \\
\hline & 20 & $73.33 \pm 0.26$ & & \\
\hline & 25 & $92.44 \pm 0.09$ & & \\
\hline \multirow[t]{5}{*}{ Compound 3} & 5 & $13.44 \pm 0.01$ & $Y=3.9124 X-7.836$ & $14.78 \pm 0.11$ \\
\hline & 10 & $29.77 \pm 0.23$ & & \\
\hline & 15 & $50 \pm 0.22$ & & \\
\hline & 20 & $69.81 \pm 026$ & & \\
\hline & 25 & $91.23 \pm 0.33$ & & \\
\hline \multirow[t]{5}{*}{ Ascorbic acid } & 5 & $2.34 \pm 0.09$ & $Y=4.806 X-21.602$ & $14.90 \pm 7.5 \mathrm{E}-3$ \\
\hline & 10 & $25.97 \pm 0$ & & \\
\hline & 15 & $51.44 \pm 0.09$ & & \\
\hline & 20 & $74.43 \pm 0.09$ & & \\
\hline & 25 & $98.26 \pm 0.17$ & & \\
\hline
\end{tabular}

phenolic content may directly contribute to their antioxidant action. In free radical scavenging assay, it was noted that DPPH scavenging activity increased with the increase in concentration for both standard and methanol extract of $H$. scabra. The results indicated that the crude extracts contain free radical scavenging activities which exert a beneficial action against pathological alterations caused by the generation of free radicals. The total phenolic contents in the crude extracts from $30.52 \pm 0.21 \mathrm{GAE} / \mathrm{g}$ friedelin (1), 3-hydroxybenzaldehyde (2) and 4-hydroxybenzaldehyde (3) are strong free radical inhibitors. They have effective concentration $\left(\mathrm{EC}_{50}\right)$ values $14.63 \pm 0.01,14.62 \pm 0.01$ and $14.78 \pm 0.11 \mu \mathrm{g} / \mathrm{ml}$ and they are similar to ascorbic acid $\left(14.90 \pm 7.5 \times 10^{-3}\right)$.

Friedelin (1): white solid; mp. $251-254{ }^{\circ} \mathrm{C}$; FTIR $v_{\max }^{K B r} /$ cm: 2972, 2926, 2868, 1711, 1461, 1389, 1299, 1189, 1073, 1002, 982 and 924; HR-TOF-MS (ESI positive): $(\mathrm{m} / z$ $427.3969[\mathrm{M}+\mathrm{H}]^{+}$, calc. 427.3934$)$.

3-Hydroxybenzaldehyde (2): brown powder; mp. 121.1-122 ${ }^{\circ} \mathrm{C}$; FTIR $v_{\max }^{K B r} / \mathrm{cm} 3448$ (O-H stretching), 1644, 1611, 1545 and $779 / \mathrm{cm}$. UV $\lambda_{\max }(\mathrm{nm}, \log \varepsilon): 284$
(3.68), 221 (3.58); EIMS $m / z$ (relative intensity): 122 (33), 121 (100), 93 (24), 65 (36).

4-Hydroxybenzaldehyde (3): yellow powder; $\mathrm{mp}$. 121.1-122 ${ }^{\circ} \mathrm{C}$; FTIR $v_{\max }^{K B r} / \mathrm{cm} 3448$ (O-H stretching), 1644, 1611, 1545 and $779 \mathrm{~cm}^{-1}$. UV $\lambda_{\max }$ (nm, log $\left.\varepsilon\right): 284$ (3.68), 221 (3.58); EIMS $m / z$ (relative intensity): 122 (33), 121 (100), 93 (24), 65 (36).

In the future, $H$. scabra may be used to develop as a nutraceutical for patients with cardiovascular symptoms. It is able to support antioxidant substances causing free radical damage, such as quercetin, the flavonoids found in onion. It preserved vascular function, blood pressure, heart rate and vascular responsiveness to stress. It up-regulated endothelial nitric oxide synthase (eNOS) expression, reduced oxidative stress and maintained blood glutathione redox ratio as reported by Scicchitano et al. [20].

\section{Conclusion}

In conclusion, the methanol extract and pure compounds of whole body parts of sea cucumber showed the highest antioxidant activity with $\mathrm{EC}_{50}$ value of $33.77 \pm 0.24$, 
$14.63 \pm 0.01,14.62 \pm 0.01$ and $14.68 \pm 0.11$. It also showed the highest total phenolic content at $30.52 \pm 0.21 \mathrm{GAE} / \mathrm{g} \mathrm{d}$ wt.

\section{Authors' contributions}

TP and SC cultured and collected sample from the Coastal Fishery Research and Development Center, Prachuap Khiri Khan Province, Thailand. SN, PS and PT designed the experiment. SN performed the experiments, analysed data and wrote the paper. YT, JP, RT and MS reviewed and checked all the details. All authors read and approved the final manuscript.

\section{Author details}

${ }^{1}$ Nakhonsawan Campus, Mahidol University, 402/1 Moo 5 Khaothong, Phrayuhakiri District, Nakhonsawan 60130, Thailand. ${ }^{2}$ Department of Chemistry and Center of Excellence for Innovation in Chemistry (PERCH-CIC), Faculty of Science, Mahidol University, Rama VI Road, Bangkok 10500, Thailand. ${ }^{3}$ Department of Anatomy, Faculty of Science, Mahidol University, Rama VI Road, Bangkok 10500, Thailand. ${ }^{4}$ Coastal Fishery Research and Development Center, 448 Moo 1 Klongwan, Mueng Prachuap Khiri Khan District 77000, Prachuap Khiri Khan, Thailand.

\section{Acknowledgements}

This research project was supported by Mahidol University, the Office of the Higher Education Commission (CHE-RES-RG). We thank Nakhonsawan campus Mahidol University. Finally, we would like to thank Associate Professor Vasakorn Bullangpoti and Dr. Paskorn Muangphrom for their advice and valuable discussion during this research work.

\section{Competing interests}

The authors declare that they have no competing interests.

\section{Availability of data and materials}

All data are shown in Table 1.

\section{Consent for publication}

This research has been confirmed to publish in the journal.

\section{Funding}

This work is financially supported by Talent Management Fund for Mahidol University.

Received: 21 November 2016 Accepted: 17 January 2017

Published online: 02 March 2017

\section{References}

1. Mariusz G, Slawomir K. A study of free radical chemistry: their role and pathophysiological significance. Acta Biochimica Polomica. 2012;1:1-16.

2. Halliwell B. Antioxidant defence mechanisms: from the beginning to the end (of the beginning). Free Radic Res. 1999;31:261-72.
3. Young IS, Woodside JV. Antioxidants in health and disease. J Clin Pathol. 2001;54:176.

4. Abheri DS, Anisur RM, Ghosh AK. Free radicals and their role in different clinical conditions: an overview. IJPSR. 2010;1 (3):185.

5. Dictionary of natural product. Abingdon: Taylor \& Francis Group. 2016. http://dnp.chemnetnase.com. Accessed 15 Nov 2016

6. Percival M. Antioxidants. Clin Nutr Insights. 1996:1:1-4.

7. Setyastuti A. Echinodermata, Holothuria atra, in an intertidal seagrass bed off the Bama beach, Bakura National park, East Jawa, Indonesia. Jurnal IImu dan Teknologi Kelautan Tropis. 2012;6(1):31-9.

8. Derek JS, Christopher EB, Robert JT. Gateways to Hawai'i: genetic population structure of the tropical sea cucumber Holothuria atra. J Mar Biol. 2011;2011:1-17.

9. Sergey D, Iman MAM, Bassam S. Bioactive compounds from Omani sea cucumber. Agric Mar Sci. 2009;14:49.

10. Arash S, Fatemeh N, Neda A, Abdolghani A. The investigation of antibacterial activity of Holothuria leucospilota sea cucumber extracts (Body Wall, Guts and White Strings) at Chabahar Bay in Oman Sea. Env Stud Persian Gulf. 2014;1 (2):135-40.

11. Kanjana A, Rapeepun V, Charoonroj C, Saksit N, Thanakorn R, Boonsirm W. Scabraside D extracted from Holothuria scabra induces apoptosis and inhibits growth of human cholangiocarcinoma xenografts in mice. Asian Pac J Cancer Prev. 2016;17(2):511-7.

12. Shimada S. Antifungal steroid glycoside from sea cucumber. Science. 1969;163:3874

13. Isaac D, Dhinakaran AP. Lipton Studies on the bioactivity of Holothuria atra extracts collected from the South east coast of India. Int J Biol Biol Sci. 2014;3(1):6-10.

14. Jean-Fancois H, Chantal C, David LP, Annie M. The sea cucumber Holothuria scabra (Holothuroidea: Echinodermata): Its biology and exploitation as Beche-de-mer. Adv Mar Biol. 2001:41:1-104.

15. Annie M, Stephen C, Jean-Fancois H. Periodic movement, recruitment and size related distribution of sea cucumber Holothuria scabra in Solomon Islands. Hydrobiologia. 2000;440:81-100.

16. Grasiely FS, Lucienir PD, Antônio FCA, Grácia DFS, Sidney AVF, Roqueline RS, Djalma MO, Jacqueline AT. New triterpenes from Maytenus robusta: structural elucidation based on NMR experimental data and theoretical calculations. Molecules. 2012:17:13439-56.

17. Kai B, Aixue F, Yi D, Liang Z, Weige Z, Maosheng C, Xinsheng Y. Selective demethylation and debenzylation of aryl ethers by magnesium iodide under solvent-free conditions and its application to the total synthesis of natural products. Org Biomol Chem. 2009;7:5084-90.

18. Brand-Williams W, Cuvelie ME, Berset C. Use of a free radical method to evaluate antioxidant activity. Lebensm.-Wiss. u.-Technol. 1995;28:25-30.

19. Gabriel AA, Joe AV, Patrick ED. Folin-ciocalteau reagent for polyphenolic assay. IJFS. 2014:3(8):147-56.

20. Scicchitano P, Cameli M, Maiello M, Modesti PA, Muiesan ML, Novo S, Palmiero P, Saba PS, Pedrinelli R, Ciccone MM. Nutraceuticals and dyslipidaemia: beyond the common. J Funct Foods. 2014;6:11-32. 